\title{
PENGELOLAAN SUMBERDAYA PERIKANAN DALAM KERANGKA UNDANG-UNDANG OTONOMI DAERAH
}

\author{
Johan Erwin Isharyanto *
}

\begin{abstract}
The fishery and marine sector is one of the sectors that is expected to contribute to the recovery efforts of the Indonesian economy. However, marine and fishery development as the main pillar of the national economy still requires the struggle and endless hard work of all its stakeholders. Regional autonomy requires the Region to participate and be responsible in the development process in its own region in the framework of realizing equitable development. This article concludes that Article 18 of Law no. 32 of 2004 became the basis of legal construction that designed the scenario of autonomous management of fishery resources in regions that have marine territory by giving authority to manage resources in marine areas. The lack of clarity on the regulation of autonomous authority over control of marine fisheries resources among regions has the potential to result in interpretations that are not in line with the law and the conflict between marine fishery resources between regions.
\end{abstract}

Keywords: Fishery Resources, Regional Autonomy

\section{PENDAHULUAN}

Berdasarkan data yang ada, Indonesia sebagai negara kepulauan mempunyai lebih dari 17,5 ribu pulau, dengan wilayah pengelolaan perikanan sekitar 5,8 juta $\mathrm{km} 2$. Sekitar $2 / 3$ dari keseluruhan wilayah Nusantara adalah perairan dengan potensi sumber daya ikan yang melimpah dan tersebar di seluruh perairan Indonesia. Sumber daya ikan yang hidup di wilayah perikanan Indonesia dinilai memiliki tingkat keragaman hayati yang paling tinggi. Dengan besarnya potensi tersebut prospek untuk membangun perikanan Indonesia menjadi salah satu kegiatan ekonomi yang strategis. ${ }^{1}$

* Johan Erwin Isharyanto, Dosen Fakulatas Hukum UNTAG Semarang Dapat di hubungi melalui email : hukumtag@yahoo.com

1 Husni Manggabarani, Tinjauan Wilayah Pengelolaan Perikanan dan Implikasinya bagi Pemanfaatan Ruang Wilayah Laut, Makalah pada Seminar Nasional Strategi Pemanfaatan Ruang laut Nasional, Jakarta, 2003,
Sumberdaya perikanan adalah sumberdaya yang dapat pulih (renewable) yang berarti bahwa apabila tidak terganggu, maka secara alami kehidupan akan terjaga keseimbangannya, dan akan sia-sia bila tidak dimanfaatkan. Apabila pemanfaatan nya tidak seimbang dengan daya pulihnya maka sumberdaya tersebut dapat terdegradasi dan terancam kelestariannya.

Prinsip dasar yang mendasari ide pengelolaan adalah bahwa pemanfaatan sumberdaya harus didasarkan pada sistem dan kapasitas daya dukung (carrying capacity) alamiahnya. ${ }^{2}$

Salah satu pertanyaan mendasar dalam pengelolaan sumberdaya ikan adalah bagaimana memanfaatkan sumberdaya tersebut sehingga menghasilkan manfaat ekonomi yang tinggi bagi pengguna, namun kelestariannya tetap terjaga. Secara implisit pertanyaan tersebut mengandung dua makna, yaitu makna ekonomi dan makna

2 Saputra, Suradi Wijaya. Dinamika Populasi Ikan Berbasis Riset. Badan Penerbit Universitas Diponegoro. Semarang, 2009. 
konservasi atau biologi. Dengan demikian, pemanfaatan optimal sumberdaya ikan mau tidak mau harus mengakomodasi kedua disiplin ilmu tersebut. Oleh karena itu, pendekatan bio - ekonomi dalam pengelolaan sumberdaya ikan merupakan hal yang harus dipahami oleh setiap pelaku yang terlibat dalam pengelolaan sumberdaya ikan.

Diratifikasinya United Nation Convention On The Law Of The Sea (UNCLOS) 1982 melalui Undang-undang Nomor 17 Tahun 1985 merupakan pijakan perjuangan Negara Republik Indonesia dalam memiliki hak untuk memanfaatkan, konservasi, dan pengelolaan sumber daya ikan di zona ekonomi eksklusif Indonesia dan laut lepas yang dilaksanakan berdasarkan persyaratan atau standar Internasional yang berlaku.

Sektor perikanan dan kelautan menjadi salah satu sektor yang diharapkan dapat memberikan kontribusi terhadap upaya pemulihan perekonomian Indonesia. Tugas ini tentu tidak ringan, tapi juga bukan hal yang mustahil. Paling tidak ada 5 alasan yang mendasari optimisme sektor ini. Selain faktor kekayaan sumberdaya alam (natural resources endowment) yang dimiliki, menjadikan sektor perikanan dan kelautan sebagai penggerak utama (prime mover) ekonomi nasional juga didasari oleh kenyataan bahwa, pertama, dengan semakin meningkatnya jumlah penduduk dunia dan kesadaran akan pentingnya kualitas gizi pangan maka permintaan produk perikanan diperkirakan akan semakin tinggi. Kedua, terkait dengan peningkatan permintaan ini, maka sektor perikanan dan keluatan mampu menghasilkan backward and inward linkages economies dalam struktur perekonomian nasional. Ketiga, dengan berbasis pada sumberdaya alam terbarukan (renewable resources), maka basis pembangunan berkelanjutan dapat diwujudkan. Keempat, pengembangan sektor perikanan dan kelautan termasuk pulau-pulau kecil dapat membantu mengatasi persoalan perbatasan dan revitalisasi fungsi ekonomi, ekologis, budaya dan hankam dari pulau-pulau kecil dan atau pulau terpencil (remote islands) serta menciptakan distribusi kesejahteraan antar wilayah.Keenam, fokus ke laut menjadikan Indonesia kembali sadar (reinventions) bahwa secara budaya, masyarakat Indonesia tidak dapat dilepaskan dari wilayah pesisir dan laut. ${ }^{3}$

Namun demikian, secara empiris harus diakui bahwa pembangunan kelautan dan perikanan sebagai penopang utama ekonomi nasional masih memerlukan perjuangan dan kerja keras tanpa henti dari seluruh stakeholders-nya.

Salah satu produk reformasi adalah ditetapkannya otonomi daerah melalui Undang-undang No. 22 tahun 1999 tentang Pemerintahan Daerah yang kemudian diganti dengan Undang-undang No. 32 tahun 2004 tentang Pemerintahan Daerah.

Otonomi daerah dirancang untuk mengoreksi pola pembangunan yang sentralistik sebagaimana dipraktekkan selama Orde Baru. Undang-undang inii juga dirancang sebagai langkah peningkatan partisipasi dan tanggung jawab daerah dalam proses pembangunan di daerahnya sendiri dalam kerangka mewujudkan pembangunan yang berkeadilan. Otonomi dianggap jauh lebih demokratis dibandingkan dengan sistem yang terpusat, bahkan lebih menjamin adanya pluralitas, karena menghindari dominasi kekuasaan berdasarkan budaya, agama atau kepercayaan/ideologi tertentu.

\section{Permasalahan}

Berdasarkan uraian latar belakang di atas maka artikel ini akan memfokuskan pada permasalahan:

\footnotetext{
3 Hanna, S. 1999. Strenthening Governance of Ocean Fishery Resources. Ecological Economics Vol. 31 : pp. 275-286.
} 
1. Bagaimana konstruksi hukum pengaturan pengelolaan sumberdaya perikanan dalam kerangka Undangundang Otonomi Daerah?

2. Implikasi yuridis apa saja yang timbul dalam pengaturan sumberdaya perikanan di Indonesia?

\section{Pembahasan}

1. Konstruksi hukum pengaturan pengelolaan sumberdaya perikanan dalam kerangka Undang-undang Otonomi Daerah.

Indonesia sebagai negara hukum termasuk kategori negara hukum modern. Konsepsi sebagai negara hukum modern ini secara konstitusional dapat dirujuk pada Pasal 1 ayat (3) Undang-Undang Dasar Negara Republik Indonesia Tahun 1945 yang menyatakan bahwa "Negara Indonesia adalah Negara Hukum". Sementara pada Alenia ke IV Pembukaan Undang-Undang Dasar Negara Republik Indonesia Tahun 1945 mengenai tujuan negara yaitu : melindungi segenap bangsa Indonesia dan seluruh tumpah darah Indonesia, memajukan kesejahteraan umum, mencerdaskan kehidupan bangsa serta mewujudkan keadilan sosial.

Pengaturan lebih lanjut mengenai tujuan negara tersebut, khususnya pada tujuan mewujudkan keadilan sosial, antara lain termuat dalam Pasal 33 UndangUndang Dasar Negara Republik Indonesia Tahun 1945. Pasal 33 ayat (3) UndangUndang Dasar 1945 menyatakan: "Bumi dan air dan kekayaan alam yang terkandung di dalamnya dikuasai oleh negara dan dipergunakan untuk sebesar-besarnya kemakmuran rakyat".

Pasal 33 ayat (3) Undang-Undang Dasar Negara Republik Indonesia Tahun 1945 tersebut sebagai dasar hak menguasai negara atas sumber daya alam (bumi, air dan kekayaan alam yang terkandung di dalamnya) mengatur pula tentang dasar- dasar sistem perekonomian dan kegiatan perekonomian yang dikehendaki dalam negara Indonesia. Sebagai dasar sistem perekonomian dan kegiatan perekonomian yang dikehendaki dalam negara Indonesia, Pasal 33 Undang-Undang Dasar 1945 bukanlah berdiri sendiri, melainkan berkaitan dengan kesejahteraan sosial. Berdasarkan pemikiran demikian, maka upaya memahami Pasal 33 tidak terlepas dari dasar pemikiran tentang kesejahteraan sosial. Atas dasar itu pula sehingga tujuan hak menguasai negara atas sumber daya alam ialah keadilan sosial dan sebesarbesarnya kemakmuran rakyat.

Keterkaitan hak menguasai negara dengan sebesar-besarnya kemakmuran rakyat menurut Bagir Manan akan mewujudkan kewajiban negara untuk:

a. Segala bentuk pemanfaatan (bumi dan air) serta hasil yang di dapat (kekayaan alam), harus secara nyata meningkatkan kemakmuran dan kesejahteraan masyarakat;

b. Melindungi dan menjamin segala hakhak rakyat yang terdapat di dalam atau di atas bumi, air dan berbagai kekayaan alam tertentu yang dapat dihasilkan secara langsung atau dinikmati langsung oleh rakyat;

c. Mencegah segala tindakan dari pihak manapun yang akan menyebabkan rakyat tidak mempunyai kesempatan atau akan kehilangan haknya dalam menikmati kekayaan alam. ${ }^{4}$

Ketiga kewajiban di atas, sebagai jaminan bagi tujuan hak menguasai negara atas sumber daya alam yang sekaligus memberikan pemahaman bahwa dalam hak penguasaan itu, negara hanya melakukan bestuursdaad dan beheersdaad dan tidak melakukan eigensdaad".

Artinya secara a contrario, apabila hak menguasai negara diartikan sebagai eigensdaad maka tidak akan ada jaminan

\footnotetext{
4 Bagir Manan, Beberapa Catatan atas rancangan Undang-undang tentang Minyak dan Gas Bumi, FH-UNPAD, Bandung, 1999, hlm. 1-2. 5 Ibid.
} 
bagi pencapaian tujuan hak menguasai negara yaitu sebesar-besarnya untuk kemakmuran rakyat.

Sumber dayaalam adalah potensi besar yang dimiliki bangsa Indonesia untuk menjalankan pembangunan. Meskipun demikian, potensi ini belum mampu memberikan kesejahteraan yang maksimal bagi seluruh rakyat. Demikian pula praktek pemanfaatan sumber dayaalam belum sepenuhnya mencerminkan keadilan ekologis. Upaya pemenuhan akses pada keadilan di sektor sumber dayaalam di Indonesia menghadapi sejumlah masalah besar. Hal ini sering kali menjadi isu sosial dan isu hukum. Isu-isu yang dimaksud adalah :

a. Ketimpangan penguasaan sumber daya alam

b. Penurunan kualitas lingkungan

c. Kemiskinan di kantung - kantung kegiatan pengelolaan sumber dayaalam

d. Konflik - konflik yang belum terselesaikan

e. Kecenderungan liberalisasi pengelolaan sumber dayaalam dengan proporsi kepemilikan modal asing yang terlalu besar

f. Kelembagaan yang tidak terintegrasi ${ }^{6}$ Pasal 33 ayat (3) Undang-Undang Dasar Negara Republik Indonesia Tahun 1945 menjadi landasan konstitusionil bagi pengaturan tentang sumber dayaalam di Indonesia melalui berbagai undang-undang seperti Undang-Undang No. 5 tahun 1960 tentang Ketentuan-ketentuan Pokok Agraria, Undang-Undang No. 26 tahun 2007 tentang Penataan Ruang, UndangUndang No. 32 tahun 2009 tentang Pengelolaan Lingkungan Hidup, UndangUndang No. 31 tahun 2004 tentang Perikanan sebagaimana telah dirubah dengan Undang-Undang No. 45 tahun 2009 tentang Perubahan Atas Undang-Undang No. 31 tahun 2004 tentang Perikanan dan

6 Materi Lokakarya Pengembangan Naskah Strategi Nasional Akses terhadap Keadilan, Konsultasi Narasumber Regional, hal. 33, Bali 16-17 April 2008. lain-lain. Keberadaan berbagai undangundang itu secara umum belum memberi kan arahan yang terintegrasi dalam penguasaan dan pemanfaatan tanah dan sumber dayaalam.

Permasalahan-permasalahan utama dalam kerangka normatif pengaturan sumber dayaalam di Indonesia meliputi :

a. Tafsir terhadap konsep Hak Menguasai Negara

b. Tumpang tindih peraturan perundangundangan yang dimaksud adalah tidak sinkronnya antara peraturan daerah di suatu daerah dengan daerah lain, juga sering terjadi pertentangan norma antara undang-undang dengan peraturan dareah sebagai regulasi yang berada di bawah undng-undang

c. Proporsi kepemilikan modal asing yang terlalu besar untuk pengelolaan sumber dayaalam strategis dan berdampak luas bagi kesejahteraan rakyat

d. Belum adanya harmonisasi penataan ruang di daerah dan jaminan ketersediaan ruang untuk kepentingan masyarakat

e. Belum adanya landasan hukum bagi lembaga dan mekanisme khusus penyelesaian konflik sumber daya alam ${ }^{7}$

Situasi yang sama menyangkut pengaturan sumber dayaalam yang belum jelas arahan pengembangannya dan tidak terintegrasi pengaturannya tampak pula pada penguasaan dan pemanfaatan sumber daya perikanan.

Pengaturan tentang hukum perikanan telah ada sejak zaman kolonial Hindia Belanda. Saat itu sudah dibentuk lima peraturan hukum nasional meliputi STAATSBLAND Tahun 1916 Nomor 157, STAATSBLAND Tahun 1920 Nomor 396, STAATSBLAND tahun 1927 Nomor 144, STAATSBLAND Tahun 1927 Nomor 145, dan STAATSBLAND Tahun 1939 Nomor 442. Setelah Indonesia merdeka peraturanperaturan tersebut masih tetap diberlakukan berdasarkan Pasal II Aturan Peralihan

7 Ibid. 
Undang-undang Dasar 1945 karena sepanjang peraturan yang baru belum dibentuk, peraturan yang lama masih berlaku.

Setelah Negara Indonesia merdeka dalam masa waktu 40 tahun kemudian dibentuk Undang-undang Nomor 9 Tahun 1985 tentang Perikanan yang diundangkan dalam lembaga Negara tahun 1985 No. 46 dan Tambahan Lembaran Negara Nomor 3299. Setelah berjalan kurang lebih delapan tahun Undang-undang tersebut diganti dengan Undang-undang Nomor 31 Tahun 2004 tentang Perikanan yang diundangkan dalam Lembaga Negara Tahun 2004 dan Tambahan Lembaga Negara Nomor 4433, dan diberlakukan pada 6 Oktober 2004. Penggantian undang-undang tersebut tidak ada maksud lain, dilakukan dengan dasar bahwa undang-undang yang lama belum dapat menampung semua aspek pengelolaan sumber daya ikan dan kurang mampu mengantisipasi perkembangan kebutuhan hukum serta perkembangan tekhnologi dalam rangka pengelolaan sumber daya ikan.

Umur dari pada Undang-undang Nomor 31 tahun 2004 juga tidak bertahan lama. Karena pada tahun 2009 kemudian mengalami revisi, penambahan beberapa Pasal melalui terbentuknya Undangundang Nomor 45 Tahun 2009 tentang perikanan.

Perubahan undang-undang tersebut dilakukan oleh karena pada kenyataannya, Undang-undang Nomor 31 Tahun 2004, lagi-lagi masih memiliki kelemahan meliputi:

a. Aspek manajemen pengelolaan perikanan antara lain belum terdapatnya mekanisme koordinasi antara instansi yang terkait dengan pengelolaan perikanan.

b. Aspek birokrasi antara lain terjadinya perbenturan keepentingan dalam pengelolaan perikanan.

c. Aspek hukum antara lain masalah penegakan hukum, rumusan sanksi, dan kompetensi pengadilan negeri terhadap tindak pidana di bidang perikanan yang terjadi di luar kewenangan pengadilan negeri tersebut.

Beberapa perubahan yang terjadi dalam Undang-undang Nomor 45 Tahun 2009 dapat dicermati. Pertama, mengenai pengawasan dan penegakan hukum yang menyangkut masalah mekanisme koordinasi antara instansi penyidikan tindak pidana perikanan, penerapan sanksi pidana (penjara atau denda), hukum acara terutama mengenai batas waktu pemeriksaan perkara, dan fasilitas dalam penegakan hukum di bidang perikanan, termasuk kemungkinan penerapan tindakan hukum berupa penenggelaman kapal asing yang beroperasi di wilayah pengelolaan Negara RI. Kedua, masalah pengelolaan perikanan antara lain ke pelabuhanan perikanan dan konservasi, perizinan, dan Kesyahbandaran. Ketiga, mengenai perluasan yurisdiksi pengadilan sehingga mencakup seluruh wilayah pengelolaan perikanan Negara RI.

Masih banyak Undang-undang yang berkaitan dengan pengaturan hukum dibidang perikanan yang tersebar dalam undang-undang lainnya. Diantaranya, dapat ditemukan dalam Undang-undang Nomor 6 Tahun 1996 tentang Perairan Indonesia, Undang-undang Nomor 43 Tahun 2008 tentang Pelayaran, Undangundang Nomor 5 Tahun 1983 tentang Zona Ekonomi Ekslusif Indonesia, Undangundang Nomor 32 Tahun 2009 tentang Perlindungan dan Pengelolaan Lingkungan Hidup (UUPPLH).

Begitu kompleksnya pengaturan regulasi dalam hukum perikanan sehingga dalam perkembangannya telah menjadi bahagian dari pengkajian ilmu pengetahuan di bidang hukum khususnya mengenai Hukum Perikanan. Ikan yang habitatnya menempati perairan dan lautan, secara otomatis penangkapan ikan akan bersentuhan dengan masalah kelestarian ekosistem dan lingkungan perairan. Hal 
demikian yang menjadi dasar filosofis, penegakan kedaulatan dan konstitusi Negara di bidang hukum perikanan. Dengan demikian bukan hal yang mengagetkan ketika masalah di bidang perikanan diklasifikasikan sebagai urusan Negara, yang meletakkan posisi Negara dalam menjalankan fungsinya untuk menciptakan ketertiban, kesemerataan dan pemanfaatan wilayah laut tanpa ada efek atau dampak yang diakibatkan dari pengelolaan sumber daya perikanan di wilayah perairan Indonesia.

Dalam bidang pengelolaan sumber daya alam dan lingkungan hidup, otonomi daerah secara garis besar berarti :

a. Menyesuaikan kebijakan pengelolaan sumber daya alam dengan ekosistem setempat.

b. Menghormati kearifan tradisional yang sudah dikembangkan masyarakat dalam pengelolaan sumber daya alam dan lingkungan hidup secara lestari

c. Tidak berdasarkan batas administrasi, tetapi berdasarkan batas ekologi (bioecoregion)

d. Meningkatkan kemampuan daya dukung lingkungan setempat dan bukan menghancurkan daya dukung ekosistem dengan eksploitasi yang melewati daya dukung

e. Pelibatan secara aktif masyarakat adat dan penduduk setempat sebagai pihak yang paling berkepentingan dalam pembuatan kebijakan pengelolan sumber daya alam dan lingkungan hidup.

Terkait dengan pengelolaan sumber dayalaut Pasal 18 ayat (1) Undang-undang No. 32 tahun 2004 menyatakan bahwa Daerah yang memiliki wilayah laut diberikan kewenangan untuk mengelola sumber daya di wilayah laut.

Selanjutnya Pasal 18 ayat (3) Undang-undang No. 32 tahun 2004 mengatur bahwa Kewenangan untuk mengelola sumber daya di wilayah laut meliputi: a. eksplorasi, eksploitasi, konservasi, dan pengelolaan kekayaan laut;

b. pengaturan administratif;

c. pengaturan tata ruang;

d. penegakan hukum terhadap peraturan yag dikeluarkan oleh daerah atau yang dilimpahkan kewenangannya oleh Pemerintah;

e. ikut serta dalam pemeliharaan keamanan;

f. ikut serta dalam pertahanan kedaulatan negara.

Dengan demikian dalam skenario Otonomi Daerah terkandung pula di dalamnya konstruksi hukum terkait designaktivitas pengelolaan sumber daya perikanan.

Pertama, sudah seharusnya daerah mengetahui potensi perikanan serta batasbatas wilayahnya sebagai dasar meregulasi pengelolaan sumber daya, seperti penentuan jenis dan tipe kegiatan perikanan yang sesuai di daerahnya;

Kedua, daerah dituntut bertanggung jawab atas kelestarian sumber daya perikanan dan sumber daya ikan di daerahnya.

Ketiga, semakin terbuka peluang bagi bagi masyarakat lokal (nelayan) untuk terlibat dalam proses pengelolaan sumber dayaperikanan.

Pemberian kewenangan yang sedemikian luas kepada daerah sudah tentu diharapkan merupakan berkah bagi daerah yang bersangkutan, terutama dalam meningkatkan Pendapatan Asli Daerah (PAD). Namun demikian perlu disadari, bahwa di balik kewenangan yang luas itu terkandung pula potensi konflik antar daerah yang berbatasan. Konflik ini sangat mudah muncul apabila pada batas wilayah laut itu kaya akan sumber daya alam/ikan yang sangat potensial untuk peningkatan PAD, sementara batas wilayah laut belum ditetapkan dan berlaku secara definitif. ${ }^{8}$

\footnotetext{
8 Soejito, Aspek Yuridis Penetapan Batas Wilayah Laut dalam kerangka Otonomi Daerah, Jurnal Mimbar Hukum, Fakultas Hukum UGM, No.42/X/2002, hlm.20.
} 
Pasal 18 ayat (4) Undang-undang No.32 tahun 2004 mengatur bahwa kewenangan untuk mengelola sumber daya di wilayah laut paling jauh 12 (dua belas) mil laut diukur dari garis pantai ke arah laut lepas dan atau ke arah perairan kepulauan untuk provinsi dan $1 / 3$ (sepertiga)dari wilayah kewenangan provinsi untuk kabupaten/kota.

Pasal 18 ayat (5) Undang-Undang No. 32 tahun 2004 yang mengatur wilayah laut antara 2 (dua) provinsi kurang dari 24 (duapuluh empat) mil, kewenangan untuk mengelola sumber daya di wilayah laut dibagi sama jarak atau diukur sesuai prinsip garis tengah dari wilayah antar 2 (dua) provinsi tersebut, dan untuk kabupaten/kota memperoleh $1 / 3$ (sepertiga) dari wilayah kewenangan provinsi dimaksud.

Terhadap batas wilayah laut daerah ini, setidaknya ada dua persoalan pokok yang perlu mendapat perhatian, Pertama, sejauh ini undang-undang yang mengatur secara detail mengenai teknik-teknik penetapan batas wilayah laut belum ada. Kedua, belum semua daerah siap dan mampu melaksanakan penetapan batas wilayah laut, baik karena keterbatasan dana maupun sumber daya manusia dan peralatannya.'

\section{Implikasi yuridis yang timbul dalam pengaturan sumberdaya perikanan dalam kerangka Undang-undang Otonomi Daerah.}

Prinsip pengelolaan laut semula mendasarkan pada adagium "the Freedom of the Sea" yang diinisiasi oleh Grotius (1609), rejim pemanfaatan sumberdaya laut dikenal sebagai rejim open acces di mana hampir tidak ada batasan untuk melakukan akses terhadap sumberdaya perikanan di laut. Dalam konteks hukum laut, adagium ini merupakan awal dari perdebatan konsep pengelolaan laut antara penganut mazhab laut terbuka/bebas (mare liberum) yang

9 Ibid. dipelopori oleh Grotius dan mazhab laut tertutup (mare clausum) yang di antaranya diiniasi oleh sekelompok pemikir Inggris seperti Welwood dan Selden.

Seperti yang telah diidentifikasi oleh Charles, paling tidak ada dua makna dalam rejim open access ini, yaitu pertama, bahwa sumberdaya perikanan yang tidak tak terbatas ini diakses oleh hampir kapal yang tidak terbatas (laissez-faire) yang diyakini akan menghasilkan kerusakan sumberdaya dan masalah ekonomi. Makna kedua adalah bahwa tidak ada kontrol terhadap akses kapal namun terdapat pengaturan terhadap hasil tangkapan. Hal ini diyakini menjadi salah satu kontributor dari overkapitalisasi terhadap kapal yang didorong oleh pemahaman rush for the fish; siapa yang kuat dia yang menang. ${ }^{10}$

Indonesia, melalui penataan hukum yang menyangkut kegiatan perikanan maupun pengelolaan laut pada umumnya, memang menyebut adanya pembatasan akses terhadap wilayah penangkapan ikan. Namun demikian, pengaturan ini tidak diikuti dengan pembatasan jumlah kapal sehingga yang terjadi adalah quasi open access atau open access dalam makna kedua menurut Charles seperti yang telah diuraikan di atas. Selain itu, lemahnya penegakan hukum di laut menjadi kontributor utama dari belum berhasilnya rejim tata kelola (governance) perikanan kita. Dalam konteks ini tata kelola laut dan sumberdaya perikanan menjadi salah satu prasyarat utama sebagai bagian dari sebuah konsepsi negara kelautan terbesar (ocean state) di dunia.

Dalam konteks pemerintahan, otonomi daerah biasanya dilihat dari tiga dimensi: Pertama, otonomi negara dalam berhubungan dengan kekuatan yang ada dalam masyarakat (terutama masyarakat ekonomi dan politik); kedua otonomi pemerintah daerah akan berhubungan dengan pemerintah pusat, Ketiga, otonomi

10 Charles, A.T. 2001. Sustainable Fishery Systems. Blackwell Sciences. London, UK. 
unit-unit bawahan mengadakan organisasi pemerintahan dalam hubungan dengan unit yang lebih tinggi.

Dalam tiga dimensi itu terkandung satu nilai pokok, yaitu adanya keleluasaan untuk berprakarsa dan berkreasi. Implikasi dari adanya otonomi adalah tumbuhnya suasana kompetisi yang sehat untuk mengejar kemajuan bersama. ${ }^{11}$

Istilah otonomi mempunyai makna kebebasan, atau kemandirian (zelfstand igheid) tetapi bukan kemerdekaan (onafhankelijkheid). Kebebasan yang terbatas atau kemandirian itu adalah wujud pemberian kesempatan yang harus dipertanggungjawabkan. Dalam pemberian tanggung jawab terkandung dua unsur, yaitu:

a. Pemberian tugas dalam arti sejumlah pekerjaan yang harus diselesaikan serta kewenangan untuk melaksanakannya.

b. Pemberian kepercayaan berupa kewenangan untuk memikirkan dan menetapkan sendiri bagaimana menyelesaikan tugas itu. ${ }^{12}$

Mengamati makna atau hakekat otonomi di atas, maka dalam penerapannya, pemerintah harus memperhatikan 3 kewajiban sebagai berikut:

a. Melakukan pembinaan yang berupa pemberian pedoman, seperti dalam penelitian, pengembangan, perencana an dan pengawasan.

b. Memberikan standar, arahan, bimbing an, pelatihan, supervisi, pengendalian, koordinasi, pemantauan dan evaluasi.

c. Memberikan fasilitas, berupa pemberi an peluang kemudahan, bantuan dan dorongan kepada daerah agar dalam melaksanakan otonomi daerah dapat dilakukan secara efisien dan efektif sesuai dengan peraturan perundangundangan. ${ }^{13}$

11 Marzuki Nyakman, dalam buku "Otonomi daerah: Peluang dan tantangan oleh Tim Suara Pembangunan dan HUT Ke-50 RI.

12 Sarundajang, Arus Balik Kekuasaan ke Daerah, Pustaka Sinar, Jakarta, 1999, hlm 33-34
Dalam kaitan dengan pemberlakuan otonomi daerah, ternyata tidak hanya menimbulkan optimisme terhadap perbaikan lingkungan dan pengelolaan sumber daya alam, namun juga diimbangi dengan adanya kekhawatiran terhadap semakin memburuknya kondisi lingkungan. Kekhawatiran ini bukan tidak beralasan karena pelaksanaan otonomi daerah yang berkenaan dengan pengelolaan lingkungan hidup dan sumber daya alam paling tidak masih menyimpan beberapa kelemahan, yaitu : Kelemahan pertama, basis otonomi pada tingkat Kabupaten/kota dan bukan pada tingkat Provinsi akan menimbulkan ancaman terhadap pengelolaan sumber daya alam dan lingkungan, diantaranya :

a. Kemungkinan munculnya kebijakan di daerah tertentu yang akan mem pengaruhi atau merugikan daerah lainnya yang berada pada ekosistem yang sama. Ini bisa terjadi karena selama ini pembagian wilayah kabupaten/kota lebih didasarkan pada pertimbangan administratif. Padahal di banyak tempat, justru wilayah ekosistem selalu lebih luas dari pada batas-batas administratif. Karena itu setiap keputusan mengenai pengelolaan sumber daya alam dan lingkungan hidup di suatu kabupaten/kota dapat mempengaruhi ekosistem yang sama yang kebetulan terletak di kabupaten/ kota lain.

b. Kemungkinan munculnya pengelolaan pemerintahan dan sumber daya alam yang berbasis pada sukuisme. Hal ini disebabkan banyak Kabupaten di Indonesia banyak yang berdasarkan wilayah etnik atau wilayah kerajaan kecil yang berbasis suku. Di beberapa tempat malah sudah muncul kecenderungan untuk membatasi

13 HAW. Widjaja, 2005. Penyelenggaraan Otonomi Daerah di Indonesia, dalam Rangka Sosialisasi UU NO 32 Tahun 2004 tentang Pemerintahan Daerah, PT. Raja Grafindo Persada, Jakarta, hlm 134. 
pemberian izin mengelola sumber daya alam, bahkan ada pengusiran terhadap suku-suku tertentu yang melakukan pengelolaan sumber daya alam di kabupaten yang bukan wilayah asalnya. Hal ini akan menimbulkan konflik sosial yang tinggi antara satu kabupaten dengan kabupaten yang lain, yang akhirnya berpotensi menimbulkan ketegangan antar suku, dari konflik pengelolaan sumber daya alam ini.

c. Dapat meningkatkan laju eksploitasi sumber daya alam, karena mengejar peningkatan Pendapatan Asli Daerah (PAD)

Kelemahan kedua, berkaitan dengan penentuan kebijakan alokasi sumber daya alam dan perizinan seperti $\mathrm{HPH}$, pertambangan galian C, perkebunan, dan lain-lain tersentralisasi di tangan para bupati/walikota. Hal ini jelas sangat membatasi hak rakyat untuk menentukan apakah kebijakan atau perizinan tersebut mereka menerima atau tidak. Masyarakat tidak mempunyai hak veto terhadap keputusan yang menyangkut hidup mereka. Hal ini menimbulkan potensi memindah kan kekuasaan otoriter pemerintah pusat kepada pemerintah daerah.

Pada ranah praktis di lapangan, terkait dengan pemberlakuan otonomi daerah di bidang perikanan, yang sering terjadi adalah kesalahpahaman masyarakat nelayan dalam menafsirkan rumusan Pasal 18 Undang-undang No. 31 Tahun 2004 mengenai kewenangan mengelola sumber dayawilayah laut bagi daerah yang memiliki wilayah laut berupa klaim wilayah pengelolaan. Klaim tersebut dapat menimbulkan arogansi kepemilikan, yang mana wilayah tersebut hanya akan dapat dikelola ataupun dimanfaatkan oleh nelayan setempat. Kewenangan pengelola an wilayah laut sering dimaknai sebagai pemberian hak kepemilikan wilayah laut sehingga terjadi "pengaplingan" laut oleh daerah. Padahal diatur pula bahwa nelayan kecil tetap diperbolehkan mencari ikan di wilayah laut seluruh Indonesia.

Di samping itu krisis ekonomi yang melanda Indonesia telah menimbulkan pergeseran sektor ketenagakerjaan ke sektor perikanan yang mengakibatkan kapitalisasi operasi perikanan laut dalam pemanfaatan sumber daya laut. Jumlah nelayan yang beroperasi dengan beragam alat tangkap serta ukuran kapal terus meningkat, sementara luas operasi justru semakin menyempit karena penguasaan teknologi penangkapan yang tidak berkembang.

Kondisi munculnya sengketa/ konflik nelayan antar daerah berkaitan dengan pengelolaan dan pemanfaatan sumber dayaperikanan laut ini telah terjadi di beberapa tempat seperti antara nelayan Jawa Tengah dengan Kalimantan, nelayan Cirebon dengan nelayan Lampung, konflik nelayan di Kepulauan Selayar Sulawesi Selatan dan juga di perairan selat Madura.

Beberapa alasan munculnya konflik nelayan antar daerah ini antara lain karena :

a. Perebutan wilayah tangkapan sehingga terjadi kompetisi;

b. Terjadi pelanggaran jalur-jalur penengkapan ikan;

c. Klaim wilayah tangkapan berdasarkan hak ulayat laut dan undang-undang otonomi daerah

d. Perbedaan perilaku sosial budaya antara nelayan pendatang dan nelayan lokal;

e. Kecemburuan sosial hasil tangkapan. ${ }^{14}$

Fenomena-fenomena hukum yang telah dikemukakan di atas merupakan rangkaian masalah yang berujung pada konflik otonomi penguasaan sumber dayaperikanan laut antar daerah yang perlu dicari jalan keluar penyelesaiannya melalui

\footnotetext{
14 Muzammil Syafi'i, Problematika Sengketa antar Daerah sehubungan dengan Pengelolaan dan Pemanfaatan laut Berdasarkan UndangUndang. No. 31 Tahun 2004 tentang Perikanan, Makalah pada Seminar Nasional Upaya Pencegahan dan Penanggulangan Illegal Fishing dalam kaitannya dengan UU No. 31 tahun 2004, Fakultas Hukum Universitas Surabaya, Surabaya, 2006, hlm. 13.
} 
perubahan struktur legal yang mendorong ke arah yang memungkinkan terakomodasi nya kepentingan pusat dan daerah, kepentingan masyarakat lokal dan masyarakat luar daerah.

Implikasi yuridis pemberlakuan otonomi daerah di bidang pengelolaan perikanan yang kemudian senyara nyata terjadi adalahmeningkatnya eskalasi konflik sumber dayaperikanan laut antar daerah yang diakibatkan oleh migrasi nelayan ataupun kelebihan ikan di daerah tangkapan. Namun demikian secara yuridis terdapat indikasi ketidakjelasan pengaturan lingkup kewenangan otonomi penguasaan sumber dayaperikanan laut antar daerah yang mengakibatkan penafsiran yang tidak sejalan dengan yang dimaksudkan oleh undang-undang dan tumpang tindih pengaturan kewenangan pengelolaan wilayah laut antara Pusat dan Daerah.

Secara konseptual teoritis setidak nya ada beberapa hal yang perlu diidentifikasi dan direkonstruksi berkaitan dengan implikasi yuridis pemberlakuan otonomi daerah di bidang pengelolaan perikanan yaitu mengenai:

(1) Dasar pembenar atau hakekat desentralisasi kewenangan pengelola an sumber daya ikan;

(2) Urgensi dan bentuk-bentuk desentrali sasi kewenangan pengelolaan sumber daya ikan; dan

(3) Implikasi yang timbul dalam pelaksanaan desentralisasi kewenang an pengelolaan sumber daya ikan.

\section{Kesimpulan}

Pasal 18 Undang-undang No. 32 tahun 2004 menjadi dasar konstruksi hukum yang mendesign skenario otonomi pengelolaan sumber dayaperikanan di Daerah yang memiliki wilayah laut dengan memberikan kewenangan untuk mengelola sumber daya di wilayah laut.

Ketidakjelasan pengaturan lingkup kewenangan otonomi penguasaan sumber dayaperikanan laut antar daerah berpotensi mengakibatkan penafsiran yang tidak sejalan dengan yang dimaksudkan oleh undang-undang dan munculnya konflik sumber dayaperikanan laut antar daerah.

\section{Saran}

Perlu regulasi pengaturan, pelembagaan, penyiapan sumber daya manusia, peralatan dan anggaran dalam penetapan batas wilayah laut antara daerah guna mengantisipasi konflik pengelolaan dan pemanfaatan sumberdaya perikanan antara daerah.

\section{DAFTAR PUSTAKA}

Bagir Manan, 1999, Beberapa Catatan atas rancangan Undang-undang tentang Minyak dan Gas Bumi, FH-UNPAD, Bandung.

Charles, A.T. 2001. Sustainable Fishery Systems. Blackwell Sciences. London, UK.

Hanna, S. 1999. Strenthening Governance of Ocean Fishery Resources. Ecological Economics Vol. 31.

HAW. Widjaja, 2005. Penyelenggaraan Otonomi Daerah di Indonesia, dalam Rangka Sosialisasi UU NO 32 Tahun 2004 tentang Pemerintahan Daerah, PT. Raja Grafindo Persada, Jakarta.

Husni Manggabarani, Tinjauan Wilayah Pengelolaan Perikanan dan Implikasinya bagi Pemanfaatan Ruang Wilayah Laut, Makalah pada Seminar Nasional Strategi Pemanfaatan Ruang laut Nasional, Jakarta, 2003, hlm.

Marzuki Nyakman, dalam buku “Otonomi daerah: Peluang dan tantangan oleh Tim Suara Pembangunan dan HUT $\mathrm{Ke}-50 \mathrm{RI}$.

Materi Lokakarya Pengembangan Naskah Strategi Nasional Akses terhadap Keadilan, Konsultasi Narasumber Regional, hal. 33, Bali 16-17 April 2008. 
Johan Erwin Isharyanto : Pengelolaan Sumberdaya Perikanan Dalam Kerangka .....

Muzammil Syafi'i, 2016, Problematika Sengketa antar Daerah sehubungan dengan Pengelolaan dan Pemanfaatan laut Berdasarkan Undang-Undang. No. 31 Tahun 2004 tentang Perikanan, Makalah pada Seminar Nasional Upaya Pencegahan dan Penanggulangan Illegal Fishing dalam kaitannya dengan UU No. 31 tahun 2004, Fakultas Hukum Universitas Surabaya, Surabaya.

Saputra, Suradi Wijaya. 2009, Dinamika Populasi Ikan Berbasis Riset. Badan Penerbit Universitas Diponegoro. Semarang.
Sarundajang,1999,Arus Balik Kekuasaan ke Daerah, Pustaka Sinar, Jakarta.

Soejito, Aspek Yuridis Penetapan Batas Wilayah Laut dalam kerangka Otonomi Daerah, Jurnal Mimbar Hukum, Fakultas Hukum UGM, No.42/X/2002.

Undang-Undang No. 32 Tahun 2004

Undang-Undang No. 45 Tahun 2009 